\title{
Designing Online Interaction to Address Disciplinary Competencies: A Cross-Country Comparison of Faculty Perspectives
}
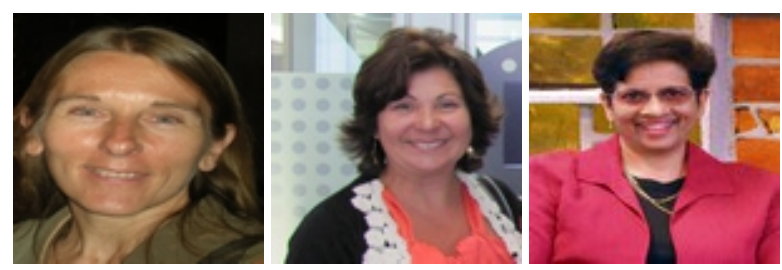

Elena Barberà' ${ }^{1}$, Ludmila Layne ${ }^{2}$, and Charlotte N. Gunawardena ${ }^{2}$

1 Universitat Oberta de Catalunya, Spain, 2University of New Mexico, USA

\section{Abstract}

This study was conducted at colleges in three countries (United States, Venezuela, and Spain) and across three academic disciplines (engineering, education, and business), to examine how experienced faculty define competencies for their discipline, and design instructional interaction for online courses. A qualitative research design employing indepth interviews was selected. Results show that disciplinary knowledge takes precedence when faculty members select competencies to be developed in online courses for their respective professions. In all three disciplines, the design of interaction to correspond with disciplinary competencies was often influenced by contextual factors that modify faculty intention. Therefore, instructional design will vary across countries in the same discipline to address the local context, such as the needs and expectations of the learners, faculty perspectives, beliefs and values, and the needs of the institution, the community, and country. The three disciplines from the three countries agreed on the importance of the following competencies: knowledge of the field, higher order cognitive processes such as critical thinking, analysis, problem solving, transfer of knowledge, oral and written communication skills, team work, decision making, leadership and management skills, indicating far more similarities in competencies than differences between the three different applied disciplines. We found a lack of correspondence between faculty's intent to develop collaborative learning skills and the actual development of them. Contextual factors such as faculty prior experience in design, student reluctance to engage in collaborative learning, and institutional assessment systems that focus on individual performance were some of these reasons.

Keywords: Instructor competencies; interaction; higher education; online learning 


\section{Introduction}

With the global expansion of eLearning, and the ability to share academic courses between countries, one question that is in the minds of many distance educators is whether a course designed in a specific discipline to address specific competencies in one country will be relevant for students of the same discipline in another country. If we are able to address this question adequately, academic courses can be designed, adapted, and exchanged internationally. Therefore, it is important to examine how academic disciplines define and communicate the culture of their discipline in online course designs, and how a discipline stipulates the competencies that need to be developed.

While many definitions of disciplinary competency exist, it is generally accepted that competencies are more than knowledge and skills; "It involves the ability to meet complex demands, by drawing on and mobilising psychosocial resources (including skills and attitudes) in a particular context" (Pisa report, p. 4). This definition is clarified by this Pisa report using the example of the competency to communicate effectively, which may draw on an individual's knowledge of language, practical IT skills and attitudes towards those with whom he or she is communicating. The OECD's Definition and Selection of Competencies Project (Rychen \& Salganik, 2001) emphasizes the key role that "context" plays in defining competencies as no frame of reference is neutral; theoretical approaches and analytical tools impact the way in which a topic is understood or problem is approached; individual characteristics such as gender, social status, culture and national context influence the form the competencies take in a specific context; and the interdependence of scientific findings and requirements of educational policy makers factor into the debate of defining a competency.

Stark (2000) notes that his empirical research confirmed previous studies which asserted that course design is closely related to enduring assumptions embedded in the disciplines and educational beliefs to which faculty members have been socialized. He further elaborates that faculty are also influenced, but less strongly, by contextual factors that depend on the local situation. In addition, the notions of interaction and competency are core concepts for understanding the interpersonal (interaction) and the intrapersonal (competency) dimensions of education. Both constructs are influenced, if not determined, socioculturally (Monaghan, Goodman, \& Meta Robinson, 2012). However, there has been very little research on how both these constructs, interaction and competency function within a discipline in a specific context, for example for a specific group of learners, in a specific academic setting, in a specific country. Such an understanding is necessary if the same course in a specific discipline is to be shared by people in different contexts.

"Most empirical research supports the view that there are important cultural differences between disciplinary groupings" (Nesi \& Gardner, 2006, p. 99). Teaching and learning Mathematics is different from teaching and learning Philosophy, for example, and effective ways to teach and learn Mathematics will differ from instructor to instructor 
and context to context. As Cameron (2008) noted, even within a discipline, there may be a need to approach the same subject in different ways to meet the learning needs of diverse students. Therefore, the design of the learning process, and a significant aspect of this learning process, that of interaction between the instructor and learners, and between learners will be designed differently. The question then is, how do these disciplinary differences and contextual differences impact online interaction and the way instructors design the instructional process? This research aims to examine this question from the perspectives of experienced online instructors in three disciplines in three countries, the United States, Venezuela, and Spain. This investigation will contribute to our understanding of how interaction is currently being designed to support the development of disciplinary competencies. We want to explore how knowledge is framed by each discipline, and what kinds of strategies promote developing competencies online.

\section{Purpose of the Study}

The aim of this paper is to report on a study conducted in higher education institutions in three countries (United States, Venezuela, and Spain) and across three disciplines (engineering, education, and business) to determine how experienced faculty identify competencies for their disciplines and design instructional activities to develop these competencies in online courses. The study also seeks to explore if disciplinary or local contextual factors take precedence when competencies are identified as important by experienced online faculty.

\section{Research Questions}

The research questions that guided this study were:

1. What academic competencies are important to experienced online instructors in their respective disciplines and what are the similarities and differences in their use of disciplinary competencies?

2. How do experienced online instructors design online interaction to develop the necessary knowledge and skills and what are the similarities and the differences found in the three countries?

Based on the identified competencies and corresponding types of interaction designed to facilitate the learning process to support the development of these competencies, implications for online instructional design will be presented along with a discussion of whether it would be possible to share the same course globally in the disciplines studied.

\section{Review of Literature}

Disciplinary knowledge and variations between disciplinary cultures (that have certain norms, beliefs, expectations, and conventions) have been defined using the seminal work of Biglan (1973), who described disciplines along three dimensions: hard/soft, 
pure/ applied, life/non-life. Subsequently, Squires (2005) made a distinction between the pure disciplines and the applied 'professional' disciplines such as Education and Medicine, observing that while the main concern in the pure disciplines is to interpret or understand the world, the professional disciplines are more focused on acting. The three disciplines selected for study in this paper can be classified as professional disciplines that are focused on application of knowledge.

Previous research in distance education has addressed the subject of disciplinary competencies (e.g., Bigatel et al., 2012; Kelly, Luke, \& Green, 2008; Hunter, 2008). Although there are exceptions (e.g., Silius et al., 2012), most of this research has focused on defining general or basic competencies for large populations (citizens of a country, a continent, and world-wide learners). In general we can distinguish between a set of studies conducted intra-nationally (e.g., Hong \& Jung, 2012) and a set of studies conducted cross-nationally (e.g., Pfeffer, 2012). Although this body of literature considers context in relation to the notion of competency, it does so at such a general level by reflecting what is common in one nation or a region of the world. These results are not very helpful in designing specific online instructional activities (Gorsky, Caspi, Antonovsky, Blau, \& Mansur, 2010) that might translate across countries. There have been a few attempts (notably Boon and van der Klink, 2002 in the USA; Eraut, 1994 in the UK) to situate competencies in terms of contextual practices (Jeris \& Johnson, 2004). This line of research examining contextual factors that influence faculty in designing the learning process is important and needs to be extended further. The current study proposes to do this by examining if contextual factors influence one of the most important aspects of the learning process: the design of interaction in online courses.

A significant body of research (J uwah, 2006) has examined the concept of interaction in distance education since Moore (1989) defined three types of interaction in an editorial published in The American J ournal of Distance Education: learner-content, learnerlearner, learner-instructor. Learner-technology interaction was added later as it has significant importance in distance and online education. This paper uses Moore's definition of interaction in distance education with a focus on learner-instructor and learner-learner interaction. Research on interaction has focused mainly on six important aspects: a) the types of interaction (Bernard et al., 2009; Gilbert \& Moore, 1998); b) the levels of interaction (Erdogan \& Campbell, 2008; Kale, 2008); c) the taxonomies of interaction (Fulford \& Sakaguchi, 2002; Nandi, Hamilton, \& Harland, 2012); d) the patterns of interaction (Loewen \& Reissner, 2009; Manca, Delfino, \& Mazzoni, 2009; Abedin, Daneshgar, \& D'Ambram, 2012); e) the design of interaction (Hurumi, 2006; Juwah, 2006; Tsai \& Lee, 2012); and f) the evaluation of interaction (Guan, Tregonning, \& Keenan, 2008; Snášel et al., 2012). It is generally accepted that interaction is a critical ingredient of a quality online course (Masoumi \& Lindström, 2012; Keengwe \& Schnellert, 2012, Quality Matters, 2011). Nevertheless, interaction is not commonly part of the design of an online course as maintaining quality interaction in an online course requires faculty time and resources. A large proportion of online courses are designed to be self-instructional learning experiences with a minimal amount of learner engagement and interaction with the course professor. Although 
instructional design itself has made great efforts to include decisions about interaction in its framework, it seems there is a need in online education to move beyond the delivery of content that is currently being reinforced by some massive open courses around the globe. Therefore, a richer conception of interaction can help to design more balanced and effective online teaching and learning based on authentic knowledge building.

Interaction in an online course is a critical factor as it reflects student engagement (Roblyer \& Wiencke, 2004). Interaction is influenced and shaped by many factors. One important factor is context, as it shapes the way faculty will design a course to meet the needs and expectations of a certain group of learners, a program, institution, or country. Stark, Lowther, Bentley, and Martens (1990) studied several disciplines and identified through factor analysis eight contextual influences on faculty course planning. The level of importance of these factors in order of rank are: 1 Student characteristics, 2 Student goals, 3 Pragmatic issues, 4 Influences external to the college or university, 5 (tie) Program and college goals, 5 (tie) Advice available on campus, 5 (tie) Literature on teaching and learning, and 6 Facilities, resources, opportunities, assistance. These eight factors and others, such as "teaching presence," "cognitive presence," and "social presence" that showed a significant relationship between academic discipline and dialogic behavior in Gorsky et al.'s (2010) study should be considered as we look at the relationship between disciplinary competencies and interaction.

\section{Method}

A qualitative research design based on in-depth interviews with online faculty was selected as the method for this study. The study was designed by the three authors of this paper in 2007, and Institutional Review Board (IRB) approval granted for this international study by the U.S. institution the same year. The study was completed in higher education institutions in Spain, the United States, and Venezuela. These institutions included one that was a wholly online institution from Spain (hereafter referred to as 'Spain'), one that was a dual-mode (traditional and distance) higher education institution from the Southwestern United States (hereafter referred to as 'US'); and four higher education institutions from Venezuela (referred to collectively as 'Venezuela,' and treated as a single unit of analysis.)

\section{Participants}

A purposeful sample of 19 experienced online faculty members was selected for interviews. The faculty were from the three countries (six from Spain, six from US, and seven from Venezuela) teaching in three diverse disciplines. These faculty members had extensive teaching experience ranging from 10 to 25 years in their respective fields. All had taught at least three courses online in their discipline. Eight faculty interviewees were from education, six from engineering, and five from business. Of the eight interviewees from the education discipline, two were from the US, four from Venezuela, and two were from Spain. The engineering sample consisted of two faculty members 
from each country. The business school sample consisted of two faculty members from the US, two from Spain, and one from Venezuela.

\section{Instruments and Procedure}

An initial set of interview questions that corresponded to the research questions was developed collaboratively by the researchers from the three countries and translated into three languages: English, Catalan, and Spanish. The interview questions were then pilot tested by doctoral students from the US university and the researchers from each university in Spain and Venezuela. Based on the pilot instrument feedback, several questions were refined and modified. The final interview guide had 26 questions, out of which three main questions and associated sub-questions were selected for analysis in this study. The main questions were: (a) In your discipline, what kinds of knowledge and skills should students have when they graduate? (b) Relative to the previous questions, which competencies do you focus on when designing interactive learning activities? (c) Are these competencies focused on individual or collaborative group work? Data collection procedures entailed the use of open-ended questions in face-toface interviews. All interviews were tape recorded and the recordings were transcribed for analysis.

Faculty interviews in the U.S. institution were conducted by one of the authors of this paper and her doctoral students, and the data analyzed for this institution by the end of 2007. Interviews were conducted in the Venezuelan institutions in 2008 by one of the authors of this paper and data analyzed for the Venezuelan institution during 20082009. The procedure for the institution in Spain was similar to the Venezuelan institution. Interviews were conducted by the primary author of this study in 2008, and subsequently, the codes verified by a graduate assistant and data analyzed for this institution in 2009. The interviews from Spain and the United States were analyzed and coded with Atlas.ti 5.0 qualitative software, while the interviews from Venezuela were analyzed manually. During 2010, the three institutions shared the findings, collaborated to analyze data and began to determine the codes and themes that emerged across institutions.

\section{Data Analysis}

An interpretative, narrative approach to data analysis was employed to examine the relationships between multiple disciplines and countries. The data analysis procedure included several steps. First, data was coded in each of the three countries and a coding list developed. Then, the coding lists were shared among the three countries, and a master coding list developed for the study. Concept mapping was used as a data analysis technique to facilitate the comparison of data across the countries and multiple disciplines. The analysis was discussed via face-to-face meetings, audio and desktop conferencing, and electronic messaging. Triangulation occurred in three ways: (a) data triangulation was achieved by gathering data from three different contexts, (b) investigator triangulation was achieved by employing several researchers to analyze the data, and (c) theory triangulation was achieved by employing three different conceptual 
frameworks (disciplinary, contextual, online interaction) to interpret the data (J anesick, 2003). These three types of triangulation helped to account for the trustworthiness and credibility of findings for similar contexts.

\section{Findings and Discussion}

The results are organized by disciplines: engineering, education and business. The results for the first research question that show how academic competencies were defined by faculty for each discipline can be seen in Table 1 . We then discuss the unique perspectives that emerged for each discipline by each country and context. Next, we discuss the competencies shared by the three disciplines (see Table 2). To address the second research question, we provide a detailed analysis of the design of interaction by discipline and by country (see Tables 3-5). We conclude by making comparisons of the salient similarities and differences across disciplines and countries, and discuss the role of disciplinary influences and contextual influences on the design of online interaction. We conclude with implications for the design of online interaction.

\section{Engineering}

\section{Q1. Academic Competencies and Engineering Profile}

From the six interviews of engineering faculty, we identified several important academic competencies. Based on faculty opinion from all three countries, these competencies involve both knowledge and experience, and the need for students to be able to function like professional engineers in the field. Students should be able to identify, and solve problems and communicate their knowledge to others. They need to be able to manage, lead, and work in teams. Therefore, engineers must possess more than content knowledge, and must have the ability to function as an engineer in the workplace. One US faculty member described it as "learning through the school of hard knocks." Therefore, when a faculty member says "knowledge of the field," it is not merely knowledge of content, but also the integration of process skills (see Table 1 for a detailed list of competencies).

These are the main competencies that define an engineer's profile: Analytical, critical thinking, problem solving, decision making, managing, evaluating, working in teams, leading, and communicating orally and in writing. Comparing our results to a previous study conducted by Davis, Beyerlein, and Davis (2005), we found several similarities in our identified profile for engineers. This study identified the main competencies for an engineer as follows: analyst, problem solver, designer, researcher, communicator, collaborator, leader, self-grower, achiever and practitioner.

We observed that the US civil engineering and the electrical and computer engineering faculty members defined knowledge of the field as constituting both knowledge and experience, which includes: 1) Understanding how industry works, for example, identifying roles and responsibilities of each player in the construction industry, 2) Experience in the field, 3) Connecting previous knowledge to new situations, 4) 
Applying critical thinking to solving problems, and 5) Conducting research. One faculty member observed: "If they don't have this knowledge and experience, it leads to confusion and litigation."

The two faculty members from Venezuela (one from civil and one from computer engineering) also emphasized the importance of both knowledge and experience, and noted that decision making in the real world context and transferring knowledge into new situations were equally important. This includes mastery of knowledge and acquiring knowledge and skills to evaluate "material strength and resistance and appropriateness in construction projects." Therefore, laboratory skills are necessary from the outset. For these two faculty knowledge of the field also included the ability to apply new knowledge into new situations, where students also have to develop skills such as analysis, critical thinking, reflection, planning strategies, decision making and be able to share and work in a team.

The two engineering faculty members from Spain, both from information technology (IT) and networking, thought of knowledge of the field more in terms of systems thinking. They stated that students must have a clear understanding of how IT systems "function," "how to trouble shoot" and "how to construct them." They should know how to assimilate this knowledge and communicate it to others. They mentioned that communication skills, both oral and written, are important for professionals in IT engineering. In addition, they emphasized the development of team and group work: "Everything is done in group projects and not individually; they must be able to work with other people to share and get used to dealing with one part of a project." Another skill that was considered important was the ability to lead teams within the company.

In summary, when comparing engineering academic competencies it can be noted that both knowledge and experience were mentioned as key factors for engineering students in all the countries. Other competencies that were emphasized are: systems thinking, communication, leadership, and team/group work skills. Online designs therefore need to focus on developing these skills to enable a student to function like an engineer while engaging them in "content" knowledge. We note that when defining engineering competencies across the three countries, disciplinary perspectives took precedence over contextual perspectives (or how a competency would differ in the context of a specific country). 
Table 1

\section{Summary of Competencies for the Three Disciplines by the Three Countries}

\begin{tabular}{|c|c|}
\hline Discipline & Competencies \\
\hline Engineering & $\begin{array}{l}\text { 1. Engage in systems thinking - understanding how an engineering system works, } \\
\text { how to trouble shoot it, and construct it. } \\
\text { 2. Connect previous knowledge to new situations } \\
\text { 3. Apply critical thinking to solving problems } \\
\text { 4. Analyze a problem, synthesize knowledge and come up with a solution } \\
\text { 5. Transfer knowledge } \\
\text { 6. Reflect } \\
\text { 7. Plan } \\
\text { 8. Make decisions } \\
\text { 9. Conduct research } \\
\text { 10. Evaluate "material strength and resistance and appropriateness in construction } \\
\text { 11. Wojects." } \\
\text { 12. Lead in groups and teams } \\
\text { 13. Manage } \\
\text { 14. Communicate orally and in writing }\end{array}$ \\
\hline Education & $\begin{array}{l}\text { 1. Demonstrate knowledge domain in their specific area. } \\
\text { 2. Act ethically } \\
\text { 3. Integrate, understand and apply pedagogical and psychological theories, in } \\
\text { their practice } \\
\text { 4. Develop a capacity to integrate theories to analyze educational problems } \\
\text { 5. Apply principles of Andragogy and management. } \\
\text { 6. Design instruction applying instructional design theories and principles, using } \\
\text { appropriate technologies to enhance interaction in online environments. } \\
\text { 7. Develop self-confidence in exploring and applying instructional technologies } \\
\text { and visioning new trends in their application } \\
\text { 8. Apply declarative, procedural and contextual knowledge about } \\
\text { using/applying instructional technologies. } \\
\text { 9. Develop capacity to innovate by applying new knowledge and technologies in } \\
\text { their practice. } \\
\text { 10. Develop leadership skills. } \\
\text { 11. Work in teams and collaborate both face-to-face and online. } \\
\text { 12. Know how to help, and help people to self-regulate and acquire autonomy. } \\
\text { 13. Develop capacity for self-reflective learning, self-evaluation. } \\
\text { 14. Conduct educational research. }\end{array}$ \\
\hline Business & $\begin{array}{l}\text { 1. Solve problems. } \\
\text { 2. Problem solve in groups. } \\
\text { 3. Develop analytical skills. } \\
\text { 4. Engage in critical thinking. } \\
\text { 5. Work in teams. } \\
\text { 6. Develop communication skills (oral and writing). } \\
\text { 7. Develop leadership skills. } \\
\text { 8. Act ethically. } \\
\text { 9. Develop capacity to ask questions and listen to answers. } \\
\text { 10. Formulate and evaluate projects. } \\
\text { 11. } \text { Contextualize course topics and content. }\end{array}$ \\
\hline
\end{tabular}


Table 2

Competencies Shared by Disciplines

\begin{tabular}{|l|c|c|c|}
\hline $\begin{array}{l}\text { Disciplines } \\
\text { Competencies }\end{array}$ & Engineering & Education & Business \\
\hline $\begin{array}{l}\text { Knowledge of } \\
\text { the field }\end{array}$ & $\mathrm{X}$ & $\mathrm{X}$ & $\mathrm{X}$ \\
\hline $\begin{array}{l}\text { Apply critical } \\
\text { thinking }\end{array}$ & $\mathrm{X}$ & $\mathrm{X}$ & $\mathrm{X}$ \\
\hline $\begin{array}{l}\text { Solving } \\
\text { problem skills }\end{array}$ & $\mathrm{X}$ & $\mathrm{X}$ & $\mathrm{X}$ \\
\hline Analytical skills & $\mathrm{X}$ & $\mathrm{X}$ & $\mathrm{X}$ \\
\hline $\begin{array}{l}\text { Communication } \\
\text { skills }\end{array}$ & $\mathrm{X}$ & $\mathrm{X}$ & $\mathrm{X}$ \\
\hline $\begin{array}{l}\text { Leadership } \\
\text { skills }\end{array}$ & $\mathrm{X}$ & $\mathrm{X}$ & $\mathrm{X}$ \\
\hline $\begin{array}{l}\text { Collaboration } \\
\text { skills }\end{array}$ & $\mathrm{X}$ & $\mathrm{X}$ & \\
\hline Act ethically & $\mathrm{X}$ & $\mathrm{X}$ & \\
\hline Research skills & $\mathrm{X}$ & & \\
\hline $\begin{array}{l}\text { Application \& } \\
\text { Transfer of } \\
\text { knowledge }\end{array}$ & & & \\
\hline
\end{tabular}

\section{Q2. Design of online instructional interaction in Engineering}

As Table 3 indicates, faculty in all three countries are designing a variety of activities for engineering students to develop individual and group competencies. The faculty member who teaches civil engineering in the US stated that she designs both individual and group activities in order to help students develop the competencies they need as civil engineers. She designs online activities where students start with examples of real world problems and have the opportunity to critically think through solutions. Students have to apply skills such as analysis and synthesis in the problem solving process. Also students develop research skills while solving their assigned problems. The electrical/computer engineering faculty member also affirmed that problem solving activities were the main focus in his class. However, this faculty member centered his class on developing individual competencies, instead of designing online activities to develop group work skills. 
Table 3

Competencies and Design of Interaction for Engineering Across Three Countries.

\begin{tabular}{|c|c|c|c|}
\hline \multirow{12}{*}{ 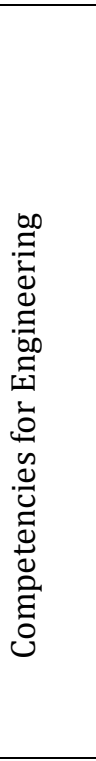 } & U.S.A. & Venezuela & Spain \\
\hline & $\begin{array}{l}\text { Understand } \\
\text { systems }\end{array}$ & & $\begin{array}{l}\text { Understand } \\
\text { systems }\end{array}$ \\
\hline & Critical thinking & Critical thinking & Critical thinking \\
\hline & Problem solving & & Problem solving \\
\hline & $\begin{array}{l}\text { Transfer of } \\
\text { knowledge }\end{array}$ & $\begin{array}{l}\text { Transfer of } \\
\text { knowledge }\end{array}$ & \\
\hline & Research skills & & \\
\hline & & $\begin{array}{l}\text { Analysis \& } \\
\text { evaluation skills }\end{array}$ & \\
\hline & & $\begin{array}{l}\text { Decision making } \\
\text { skills }\end{array}$ & \\
\hline & & Lab skills & \\
\hline & & & $\begin{array}{l}\text { Management \& } \\
\text { leadership skills }\end{array}$ \\
\hline & & & $\begin{array}{l}\text { Communication } \\
\text { skills }\end{array}$ \\
\hline & & & Build a system \\
\hline \multirow{3}{*}{ 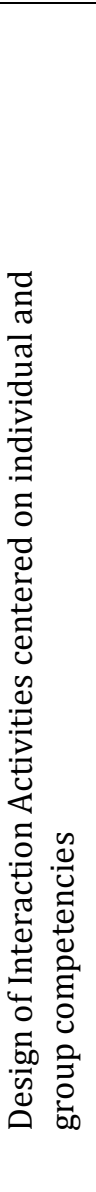 } & $\begin{array}{l}\text { Design both } \\
\text { individual and } \\
\text { group activities. }\end{array}$ & $\begin{array}{l}\text { Design learning } \\
\text { activities to } \\
\text { develop } \\
\text { competencies } \\
\text { such as: } \\
\text { Team work } \\
\text { Analysis } \\
\text { Reflection, } \\
\text { Planning action } \\
\text { strategies and } \\
\text { Decision making }\end{array}$ & $\begin{array}{l}\text { Designing group } \\
\text { project, students } \\
\text { need to show } \\
\text { leadership, } \\
\text { communication } \\
\text { and team work } \\
\text { skills used as a way } \\
\text { to the problem } \\
\text { solutions. }\end{array}$ \\
\hline & $\begin{array}{l}\text { Developing } \\
\text { individual papers } \\
\text { and presentations } \\
\text { starting with a } \\
\text { problem } \\
\text { statement, } \\
\text { students need to } \\
\text { show analysis, } \\
\text { and critical } \\
\text { thinking } \\
\text { strategies used as } \\
\text { a way to the } \\
\text { solutions. }\end{array}$ & $\begin{array}{l}\text { Designing } \\
\text { individual } \\
\text { activities where } \\
\text { student } \\
\text { demonstrate their } \\
\text { analytical } \\
\text { thinking and } \\
\text { problem solving } \\
\text { skills. }\end{array}$ & $\begin{array}{l}\text { Practical exercises } \\
\text { to be solved in } \\
\text { pairs }\end{array}$ \\
\hline & $\begin{array}{l}\text { Using example of } \\
\text { real world } \\
\text { problem that the } \\
\text { students } \\
\text { investigate. }\end{array}$ & & \\
\hline
\end{tabular}


In Venezuela, the civil engineering faculty member focuses the design of learning activities on developing individual analytical thinking, and problem solving, while the computer engineering faculty member focuses his learning activities on developing team competencies, such as team work, analysis, reflection, planning, action strategies, and decision making.

In Spain, both faculty members noted that they design more individual activities than collaborative activities. While they recognize the importance of developing teamwork skills, they take a different approach. One of them designs practical exercises to be solved in pairs, so that students can interact with each other and solve each other's problems. As he explains,

I try to make it possible for the practical exercises to be done in pairs, because by working in pairs students really help each other and if one of them gets stuck on one point and has somebody around who is working towards the same objective as him/ her and is involved in the same process, that person is able to help the student resolve the problem better than the teacher could. This is true above all when implementing a computer system, as it is possible to get stuck and the teacher does not have enough time to look at the programs that aren't working from 40 students. However, with a course colleague it is different, as you have someone with the same problem and the same desire to resolve that problem as you, which makes it much easier for him or her to give you a hand. I believe that it is very important to encourage this type of interaction, I don't intervene directly, except in the practical exercises in which the solution to the problem is complicated, I try to offer the option of working in pairs. It is important to encourage more interaction between students than with the teacher.

The second engineering/ IT faculty member designs more individual activities in the course, because

I do not feel that working in groups necessarily adds value. Group work is done more on a programmer level. The students complain because they do not want to work in groups, and although we want group working competencies to be part of the programmer, we do not want to force students.

In summary, an analysis of engineering faculty methods in all three countries indicates that they are designing instructional activities online that require students to think through problems, engage in critical thinking, and develop solutions. However, perspectives on the importance of individual and collaborative learning activities to 
meet the requirements of engineering competencies differed. Two of six faculty members are designing these activities as group work projects that require students to collaborate with each other to create solutions. While the other four faculty members acknowledge the importance of working in teams to develop leadership, management, and communication skills, they prefer to focus on developing individual problem solving and critical thinking skills. This may be related to contextual factors such as faculty experience with designing and assessing online collaborative learning, and the reluctance of students to engage in collaborative learning. It echoes Tseng and Yeh's (2013) finding that online instructors need to comprehend students' expectations on learning collaboratively. This finding may indicate the need to develop and offer faculty development programs that demonstrate how collaborative learning and evaluation strategies can be designed to correspond with student abilities and required competencies. For example, team skills can be developed in an online program by having students work in small groups to solve real world problems in a real or simulated work setting. By building online Communities of Practice that work toward a common goal, it is possible to develop team skills, leadership skills, and collaborative problem solving skills. For engineering, it can be concluded that disciplinary perspectives take precedence when faculty discuss the importance of competencies for the field, while contextual considerations impact the design of interaction, such as faculty prior experience in designing collaborative learning, to meet the needs of these competencies.

\section{Education}

\section{Q1. Academic Competencies and Education Profile}

Table 1 summarizes the competencies that emerged for education. From the eight interviews with education faculty, the competencies that emerged include application of knowledge in educational contexts, solving educational problems applying theories and new technologies, developing leadership skills, collaborating, applying instructional design principles, keeping oneself updated in new theoretical and technology trends, and developing a capacity to self-reflect and self-evaluate. Compared to the other two professions, educators stressed the importance of communication and collaboration skills, and the utilization of new technologies in instructional design. For example one of the US faculty stated:

In the program that I'm teaching they should know a lot of technologies. They should have awareness about what's coming and then a confidence that they can go out and explore new technologies and figure it out how to use them well, and how to design collaborative learning scenarios with them.

Education faculty emphasized competencies depending on their area of expertise. Of the two education faculty members interviewed in the US, one had an instructional technology background and emphasized the importance of instructional design and instructional technology competencies. The other faculty was from educational leadership and emphasized the competencies that school principals needed to develop: 
"I work in a program that primarily is committed to preparing future school leaders. Our graduates should possess the knowledge, skills and dispositions to be able to move into a beginning administrator assistant principal role in a school setting”.

Two faculty from Venezuela focused on competencies related to self-development, stressing that all educators should be conscious of their self-development which is "the ability to monitor their learning, self-reflective learning, capacity to improve their teaching skills." One of them summarized the competencies in three fundamental areas:

a) Theoretical and philosophical foundations in educational sciences, b) Use and application of methodological strategies, classroom planning, program design, and c) Instructional Design. A third respondent stated that all educators should have the capacity to integrate theories to analyze educational problems, as well as the ability to apply new knowledge in their practice. In addition, they should be able to work in groups and communities. This respondent also agreed with the previous two respondents that all educators should have the capacity to self-evaluate their practice. The fourth respondent was from educational research and therefore pointed out that all educators should be methodologically informed to investigate and apply the principles of andragogy and management.

The main competencies that emerged from the two interviews conducted in Spain were: a) knowledge of the field, b) theory application, c) ethics, d) capacity to work in teams and collaborate, e) capacity to self-reflect on their own practice, and f) capacity to selfdevelop and innovate in the field.

In summary, it was evident that the competencies considered most important depended on the specific areas of specialization within the education field the faculty came from. In all three countries, education faculty showed a common interest in the development of educators, mentioning knowledge and application of instructional technologies, capacity to work in teams and collaborate, capacity to self-reflect on their own practice, capacity to self-develop and innovate in their field, apply theories, and act ethically. Faculty from US and Venezuela noted instructional design theories and principles and the design of interaction in online environments, and research skills as important competencies.

When analyzing salient similarities and differences, three kinds of educator competencies could be distinguished. US faculty were focused on competencies that take into account specific education content, such as instructional design skills, and applying theories of learning to solve specific design problems. Faculty from Spain were driven by more general competencies such as analysis skills, research skills, and faculty from Venezuela employed a hybrid of the previous two.

\section{Q2. Design of online instructional interaction on Education}

As indicated in Table 4, both US faculty members focus on designing individual as well as interactive and collaborative learning activities, because they stated that students should develop a set of specific individual skills and autonomy in their fields, and should 
have a set of competencies that allow them to function in groups, teams, and communities. In this respect, one of them discussed the following:

(...) in educational leadership there are sets of administrative competencies that we have to align our course work with at the national and state levels. So those competencies tend to be more content focused rather than process focused. And so, with your example here, competencies that may address reflection analysis; those processes I have students write reflective papers, they do analysis, critical review, and oral and written reports. I focus on both individual as well as group competencies. 
Table 4

Competencies and Design of Interaction for Education Across Three Countries

\begin{tabular}{|c|c|c|c|}
\hline \multirow{18}{*}{ 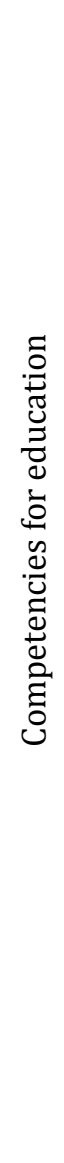 } & U.S.A. & Venezuela & Spain \\
\hline & $\begin{array}{l}\text { Instructional } \\
\text { design skills }\end{array}$ & $\begin{array}{l}\text { Instructional } \\
\text { design skills }\end{array}$ & \\
\hline & $\begin{array}{l}\text { Facilitate online } \\
\text { interaction }\end{array}$ & & \\
\hline & Critical thinker & Critical thinker & \\
\hline & Analysis skills & Analysis skills & Analysis skills \\
\hline & $\begin{array}{l}\text { Apply theories of } \\
\text { learning }\end{array}$ & $\begin{array}{l}\text { Apply theories of } \\
\text { learning }\end{array}$ & \\
\hline & Leadership skills & Leadership skills & \\
\hline & Manager skills & Manager skills & \\
\hline & & Team work & Team work \\
\hline & Technology skills & $\begin{array}{l}\text { Apply pedagogical } \\
\text { principles and } \\
\text { didactic in the } \\
\text { curriculum }\end{array}$ & \\
\hline & & $\begin{array}{l}\text { Transfer of } \\
\text { knowledge }\end{array}$ & \\
\hline & & Problem solving & \\
\hline & & $\begin{array}{l}\text { Collaborative } \\
\text { skills }\end{array}$ & $\begin{array}{l}\text { Collaborative } \\
\text { skills }\end{array}$ \\
\hline & & Research skills & Research skills \\
\hline & & $\begin{array}{l}\text { Self-reflective } \\
\text { learning }\end{array}$ & $\begin{array}{l}\text { Self-reflective } \\
\text { practice }\end{array}$ \\
\hline & & $\begin{array}{l}\text { Self-evaluation } \\
\text { skills }\end{array}$ & $\begin{array}{l}\text { Self-regulate } \\
\text { autonomy }\end{array}$ \\
\hline & & & Understand help \\
\hline & & & Act ethically \\
\hline \multirow{6}{*}{ 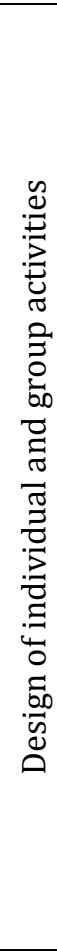 } & $\begin{array}{l}\text { Design both } \\
\text { individual and } \\
\text { group activities. }\end{array}$ & $\begin{array}{l}\text { Design both } \\
\text { individual and } \\
\text { group activities. }\end{array}$ & $\begin{array}{l}\text { Design both } \\
\text { individual and } \\
\text { group activities. }\end{array}$ \\
\hline & Videoconferences & & \\
\hline & $\begin{array}{l}\text { Design interactive } \\
\text { and collaborative } \\
\text { learning activities }\end{array}$ & $\begin{array}{l}\text { Design learning } \\
\text { activities } \\
\text { enhancing } \\
\text { collaborative } \\
\text { skills }\end{array}$ & \\
\hline & $\begin{array}{l}\text { Case-based } \\
\text { problem: } \\
\text { Solve real } \\
\text { problems in their } \\
\text { field, in group and } \\
\text { collaboratively }\end{array}$ & $\begin{array}{l}\text { Case-based } \\
\text { problems in their } \\
\text { field }\end{array}$ & $\begin{array}{l}\text { Problem solving } \\
\text { cases arguing } \\
\text { decision making } \\
\text { process }\end{array}$ \\
\hline & $\begin{array}{l}\text { Write reflective } \\
\text { papers, they do } \\
\text { analysis, critical } \\
\text { review, and oral } \\
\text { and writing } \\
\text { language query }\end{array}$ & $\begin{array}{l}\text { Write individual } \\
\text { research reports }\end{array}$ & \\
\hline & $\begin{array}{l}\text { Online discussions } \\
\text { to encourage }\end{array}$ & $\begin{array}{l}\text { Online discussions } \\
\text { to encourage }\end{array}$ & $\begin{array}{l}\text { Online } \\
\text { discussions to }\end{array}$ \\
\hline
\end{tabular}




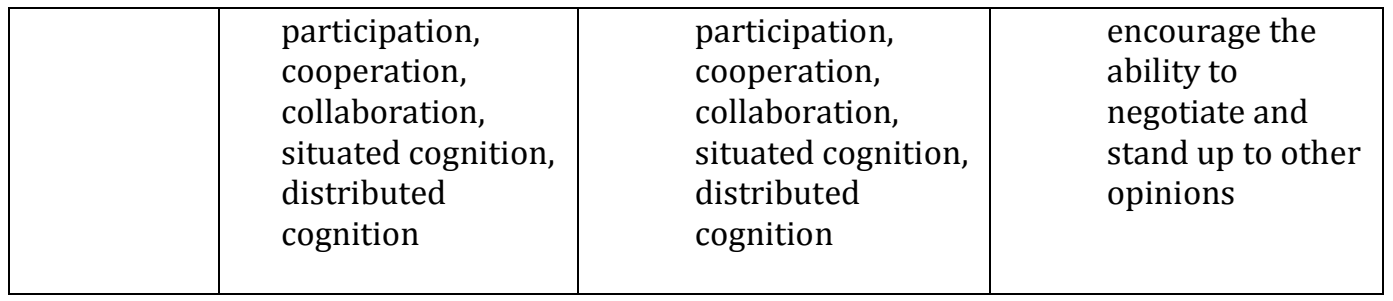

Likewise, education faculty in Venezuela, focus on developing individual as well as collaborative skills. One of them noted:

I emphasize both individual as well as collaborative skills. I design learning activities to encourage competencies such as: participation, cooperation, collaboration, situated cognition, distributed cognition, all of these in order to solve real problems in their field... Students are encouraged to write individual research reports, analyzing data into categories, then, they collaborate with each other asking questions and providing suggestions to improve their research project.

As in the cases of both US and Venezuelan education faculty, those from Spain are also designing instruction based on both individual and group competencies. One of them noted:

...reflection, decision-making and presenting arguments, and the justification for why a certain decision was made. The ability to negotiate and stand up to other opinions. All these processes are focused on group work, although I believe the students' previous individual work is also important.

This approach is corroborated by the use of online discussions which demand individual work to maintain success at the collaborative level.

Table 4 indicates that education faculty in the US, Venezuela and Spain share the common goal of designing online programs that promote collaborative and group competencies. Faculty from all three countries noted the design of case-based problem solving activities related to higher order cognitive skills such as critical, analytical thinking, problem solving, and application and transfer of knowledge. Another salient similarity between countries is the fact that they design group activities based on student-student interaction using online discussions to encourage participation, cooperation, collaboration, and communication skills.

Analysis of educator faculty perspectives on the design of interaction indicates that all faculty are designing instructional activities that help students to integrate diverse 
knowledge and skills while they are solving specific tasks and problems. Similar to other disciplines, educators are focusing on developing individual abilities such as critical thinking, applying and transferring knowledge, oral and written communication skills, and decision making. These skills have to be used in team and group activities where students demonstrate collaboration, communication, respect for the other's opinion, argumentation, group decision making, group problem solving, and critical thinking. Overall, there are trends indicating that education faculty are designing and planning more collaborative activities, and they are trying to implement collaborative tools for promoting and encouraging skilled community work, such as making decisions as a group, group communication, and strategy formation for common troubleshooting.

We conclude from this analysis that the definition of competencies by education faculty is influenced by the type of education discipline they profess. Education faculty members are more likely to take contextual factors into account as they define competencies for their profession. Compared with engineering faculty, educators are more likely to design collaborative learning activities to enhance the development of competencies related to collaboration, communication, consensus building and decision making in a group. While engineering faculty focused on content and process knowledge and developing competencies to function like an engineer, education faculty focused on developing individual and group competencies.

\section{Business}

\section{Q1. Academic Competencies and Business Profile}

Analysis for business shows three different approaches in each country: The US faculty were more concerned with developing inquiry skills such as critical thinking complemented by other skills such as leadership and conflict management. Faculty from Venezuela focused on learning techniques: "To learn a technique that allows him - the future professional - to formulate and evaluate projects". Faculty from Spain tended to be more oriented towards developing analytical skills (comprehensive reading, problem interpretation, summarizing, amongst others) to solve identified problems. Nevertheless, there is a general shared profile that comprises problem solving, analytical and critical thinking skills.

Both US business faculty members defined knowledge and competencies from a very practical and skill based perspective. While one faculty member focused more on process skills, "Being proactive, critical thinker, good writing skills, a bit of a risk taker, not afraid to ask questions.. listening to answers, acting ethically,... accountancy skills will come no matter what," the second faculty member stressed the body of knowledge covered by the course syllabus, which included organizational culture, motivation, leadership, conflict management and socialization, leadership, insights about oneself through interaction with others, ethical behavior, and analytical skills in formal organizations.

In Venezuela, the faculty members from business administration stressed the need to learn techniques that allow one to formulate and evaluate projects. Each project is 
presented as a problem to be solved and each problem requires the application of specific techniques. Faculty also focused on developing reading and analytical skills in graduate students.

Both faculty from Spain, one from economics and the other from administration focused on the development of competencies. One emphasized more interpretational and analytical skills, while the other focused on solving identified problems in groups.

In summary, business faculty in the three countries agreed on the following skills: Communication and leadership; critical thinking; and problem solving. While faculty from US and Spain agreed that team work is an important competency for the profession, faculty from Venezuela stressed analytical skills. Some notable differences in the competencies mentioned were risk taker as stated by US faculty, formulating/ evaluating projects as noted by Venezuelan faculty, and problem solving in groups as stated by faculty from Spain.

\section{Q2. Design of online instructional interaction on Business}

When asked about how faculty design interaction to develop academic competencies, the two business faculty from the US, distinguished between graduate and undergraduate competencies. They both stated that in the graduate class they design more activities involving group projects, while at the undergraduate level they design more individual learning experiences. The faculty member who focused on individual competencies said that in undergraduate classes, he assigns cases, which are not discussion based and require individual writing assignments, and the consideration of ethical behavior. In graduate classes, he assigns group projects. The other faculty member who teaches at the graduate level, focused on both developing individual skills and group skills: "I use film scenes to develop analytical skills, I show scenes and ask them to analyze it. They will sort out feelings," and "what insights they get about themselves and interaction with other people. Especially, for graduate students this is important." Currently, they both design interaction to develop individual academic competencies, yet noted the need to design more group activities in the future.

In Venezuela, the faculty member from business pointed out that he mainly focuses on enhancing individual competencies related to the capacity to be open to change, stating, "I compare how the students responses change over time during the semester". He assigned weekly quizzes to his students to evaluate their reading and analytical skills. He also mentioned that undergraduate students need much more content structure and need to learn basic skills such as the ability to analyze what they read, and to understand beyond what they read. However, he noted that his graduate students need to apply what they learn to new situations. He said that he designs his course based on the solution of problems and new techniques to solve these problems. He noted that this teaching approach is not focused on developing group competencies, but on developing individual skills and applying what they learn to new learning scenarios. "T'm interested in forming good analytical professionals capable of solving any problem that comes their way". He said that in his classes, it is optional for each student to work and study in a group. 
Faculty representing Spain who teach business and administration, affirmed that they design learning activities to be carried out individually: "The activities to achieve the competencies are more individual". While one never utilized group activity, the other acknowledged that he hardly ever plans group activities because students are reluctant to work in groups, and also because group activities are problematic in the sense that the activities need to correspond with the final exam which is an individual assignment. He explained, "If the exam disappears people will collaborate more, because now individual resolution is the thing that counts the more." This shows the constraints on team work, as students do not see much sense in doing group work if in the end they are individually assessed. These facts clearly point to a need to change grading practices and policies in higher education institutions so that collaborative team work can be rewarded.

An analysis of business faculty perspectives on the design of interaction (Table 5) indicates that they are predominantly individually oriented. All five faculty members prepare individual learning activities and only one seemed open to group work in the future because he is changing his methodology based on film scenes. Some of the arguments that made them focus on individual activities in online classes are students' reluctance to engage in group work and the individual nature of university grading practices and policies. However, this individual approach to designing learning activities contrasts with the group oriented competencies that faculty want to promote in their online classes.

We conclude that for business, competencies are designed from a predominantly disciplinary perspective with all three countries agreeing on the importance of developing analytical skills (Table 5). There were contextual variations between countries in the identification of other business skills. For example, U.S. faculty talked about the importance of leadership skills, conflict management and acting ethically, while Venezuela stressed the capacity to formulate and evaluate projects and Spain discussed the importance of team work skills. We can therefore infer that when disciplinary knowledge is put into practice, there will be variations across countries based on context. In relation to the design of interaction, all three countries focused on individual learning activities, with some hoping to develop collaborative learning activities in the future. 
Table 5

Competencies and Design of Interaction for Business Across Three Countries

\begin{tabular}{|c|c|c|c|}
\hline \multirow{16}{*}{ 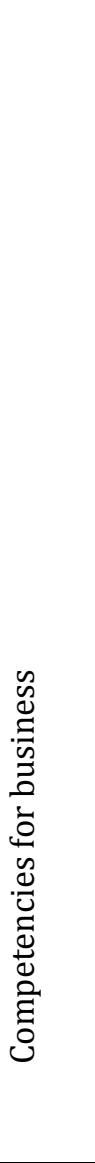 } & U.S.A. & Venezuela & Spain \\
\hline & Accountancy skills & & $\begin{array}{l}\text { Contextualize } \\
\text { course content. }\end{array}$ \\
\hline & & Problem solving & Problem solving \\
\hline & & & Team work skills \\
\hline & & & $\begin{array}{l}\text { Problem solving in } \\
\text { team }\end{array}$ \\
\hline & & $\begin{array}{l}\text { Capacity to } \\
\text { formulate and } \\
\text { evaluate projects }\end{array}$ & \\
\hline & Leadership skills & & \\
\hline & $\begin{array}{l}\text { Conflict } \\
\text { management }\end{array}$ & & \\
\hline & Act ethically & & \\
\hline & Analytical skills & Analytical skills. & $\begin{array}{l}\text { Interpretation and } \\
\text { analytical skills }\end{array}$ \\
\hline & Proactive & & \\
\hline & Critical thinker & & Critical thinker \\
\hline & $\begin{array}{l}\text { Communication } \\
\text { skills (oral and } \\
\text { writing) }\end{array}$ & Reading skills & \\
\hline & $\begin{array}{l}\text { Capacity to ask } \\
\text { question and listen } \\
\text { to the answer }\end{array}$ & & \\
\hline & Risk taker & & \\
\hline & & $\begin{array}{l}\text { Decision making } \\
\text { skills }\end{array}$ & \\
\hline \multirow{6}{*}{ 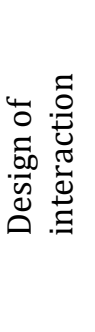 } & Individual projects & $\begin{array}{l}\text { Individual } \\
\text { projects }\end{array}$ & Individual projects \\
\hline & Group projects & & \\
\hline & $\begin{array}{l}\text { Case-based } \\
\text { problems }\end{array}$ & $\begin{array}{l}\text { Case-based } \\
\text { problems }\end{array}$ & \\
\hline & Film scenes & & \\
\hline & & Weekly quizzes & \\
\hline & & & Final Exam \\
\hline
\end{tabular}

\section{Conclusions, Implications for Design, and Future Research}

Based on our results analyzing three disciplines across three countries, we conclude that disciplinary knowledge takes precedence when faculty members select competencies to be developed in online courses for their respective professions. This finding supports Stark's (2000) empirical studies that showed that the faculty member's academic discipline exerted the strongest influence on course planning in higher education, and that to a lesser extent, the context in which they work shapes how the courses are planned and taught. 
In some cases such as the discipline of business in our study, contextual factors related to what is considered important for the profession, such as ethics, play a role in the development of additional competencies that are necessary in a particular local context. In all three disciplines, the design of interaction to correspond with disciplinary competencies was often influenced by contextual factors that modify faculty intention. What this means is that instructional design will vary across countries in the same discipline to address the local context such as the needs and expectations of the learners, faculty perspectives, beliefs and values, and the needs of the institution, the community, and country. We can therefore conclude that it is possible to design a course that will be relevant across countries from a disciplinary perspective, but it must be adapted to the local context in the design of instructional interaction and the learning process for it to be relevant to learners in that local context. Ball, Zaugg, Davies, Tateishi, Parkinson, Jensen, and Magleby (2012) identified and validated a comprehensive set of global competencies for engineering students. They found that to increasingly use collaborative engineering processes and global teams to operate on a global scale, it is necessary to think about the globalization of the traditional university's engineering curriculum. Some of the competencies identified in this study were similar to those identified in our study. However, the design of interaction to address these global competencies will differ based on the local context.

Table 2 showed a comparison of the competencies across the three disciplines selected for this study. This is of interest as it shows the type of competencies that the three disciplines from three countries agree on: knowledge of the field, higher order cognitive processes such as critical thinking, analysis, problem solving, transfer of knowledge, oral and written communication skills, team work, decision making, leadership and management skills. This indicates far more similarities in competencies than differences between the three different disciplines. Since these competencies were common to all three of the applied disciplines we studied, online course design should pay special attention to the development of these competencies. It is important to note that the interactive activities designed to develop these competencies will vary across the countries. We found a lack of correspondence between faculty's intent and desire to develop collaborative learning skills and the actual development of collaborative skills and the assessment of them.

Contextual factors such as faculty prior experience in designing collaborative learning, student reluctance to engage in collaborative learning, as well as institutional assessment systems that focus on individual performance were some of the reasons why faculty found it difficult to design collaboration even though they thought it was an important skill to develop in their learners. Ke (2013) showed that designing online interactions for deep learning does not happen naturally. In order to create more indepth, reflective and collaborative learning environments, it is necessary to observe the relationship between design and interaction. She suggests that design has a significant impact on the nature of the interaction, and whether students approach learning in a deep and meaningful manner. Tseng and Yeh (2013) conducted a qualitative study to identify important factors that were crucial for building teamwork trust. Implications for online instructors derived from this study suggest that it is important to comprehend 
students' expectations about learning collaboratively, and also understand that online collaborative learning is a more learner centered approach.

Regarding student reluctance to engage in collaborative learning as a factor influencing the design of individual activities instead of collaborative activities, similar results were found with graduate students in online environments, who were more negative about group work, and were less satisfied with group work than those who were in face-to-face sections (Gordon, Sorensen, Gump, Heindel, Caris, \& Martinez, 2011). However, these researchers suggested that given the norm of individual asynchronous work in online learning environments, online instructors should provide explicit, succinct written recommendations for how to operate in an online group environment. Alden (2011) noted the importance of faculty assessment of team efforts and suggested that grading ought to represent both (1) the quality of the product developed jointly by the team, as well as (2) the degree of participation and quality of contribution by each individual student involved in the group process. Unless students clearly see the value of group work, they are not motivated to put the extra effort to engage in collaborative learning if in the end they are individually assessed. These issues clearly point to a need to change grading practices and policies in higher education institutions to use authentic assessment (Tseng \& Yeh, 2013) so that collaborative team work in online environments can be designed appropriately and rewarded.

Our findings indicated a low correspondence between the academic competencies faculty want to develop in their students and the type of interaction and instructional activities they are currently designing in their online programs. Faculty do realize that complex skills such as problem solving and critical thinking must be developed so students can function effectively in the workplace. However, they are still not designing appropriate interactive learning activities that would enable students to engage in inquiry-based learning online to develop these complex competencies. This points to the need for faculty development in both designing interactive activities online and facilitating them. There is a need to develop a more holistic concept of interaction especially if one relies on an interaction equivalence theorem that states that meaningful and deep learning is supported as long as one of the three genuine forms of interaction is at a high level. The other two may be offered at minimal levels, or even eliminated, without degrading the educational experience. High levels of more than one of these three modes of interaction will likely provide a more satisfying educational experience, though these experiences may not be as cost or time effective as less interactive learning sequences (Anderson, 2003). In her (2013) study with 463 undergraduate online students, which showed the importance of interaction for learning, Ke advocates a balanced requirement of student-to-content, student-to-instructor, and student-tostudent interactions to promote reflective learning.

The creation of a faculty development program that would help faculty develop teaching strategies and methods that are student and community centered will bridge the gap between faculty intention and actual practice. This program would help to integrate instructional methods that are aligned with competencies. Faculty can be trained to design different types of interaction and use design aids such as visualizing tools, smart 
design advisors, tutorial examples, and create assessment rubrics and strategies that match the development of specific competencies. For example, concept maps that measure the relationship of concepts in a problem solving task, and interactive rubrics that assess collaborative learning and individual contributions to collaborative learning will assist faculty to develop more interactive and versatile learning environments online.

While we have determined from our results that an online course in a specific discipline will address similar competencies across countries, future research needs to explore in more detail the influence of context in such design, so we can determine how a course from one country can be adapted to another's local context. The main limitations of this study lie in the purposeful sample and the range of participants. A future study with more extensive participants across more disciplines and countries will enable us to have a better understanding of the correspondence between disciplinary competencies and the design of instructional interaction. 


\section{References}

Abedin, B., Daneshgar, F., \& D'Ambram, J . (2012). Pattern of non-task interactions in asynchronous computer-supported collaborative learning courses. Interactive Learning Environments. DOI:10.1080/ 10494820.2011.641676

Alden, J . (2011). Assessment of individual student performance in online team projects. J ournal of Asynchronous Learning Networks, 15(3), 5-20.

Anderson, T. (2003). Getting the mix right again: An updated and theoretical rationale for interaction. The International Review of Research in Open and Distance Learning, 4(2). Retrieved from http:// www.irrodl.org/index.php/irrodl/article/ view/ 149/230

Ball, A., Zaugg, H., Davies, R., Tateishi, I., Parkinson, A., J ensen, C., \& Magleby, S. (2012). Identification and validation of a set of global competencies for engineering students. International J ournal of Engineering Education, 28(1), 156-168.

Bernard, R. M., Abrami, P. C., Wade, A., Borokhovski, E., Tamim, R., Surkes, M., \& Bethel, E. C. (2009). A meta-analysis of three interaction treatments in distance education. Review of Educational Research, 79(3), 1243- 1289.

Bigatel, P. M., Raga, L. C., Kennan, S., May, J ., \& Redmond, B. F. (2012). The identification of competencies for online teaching success. J ournal of Asynchronous Learning Networks, 16(1), 59-77. Retrieved from http://sloanconsortium.org/jaln/v16n1/identification-competencies-onlineteaching-success

Biglan, A. (1973). The characteristics of subject matter in academic areas. J ournal of Applied Psychology, 57, 195-203.

Boon, J ., \&van der Klink, M. (2002, Feb.). Competencies: The triumph of a fuzzy concept. Proceedings of Academy of Human Resource Development Annual Conference, Honolulu, HA, 1, 327-334.

Cameron, L. (2008) Could pedagogical planners be a useful learning design tool for university lecturers? Readings in Education and Technology. Proceedings of ICICTE 2008 (pp. 496-507).

Davis, D., Beyerlein, S., \& Davis, I. (2005) Development and use of an engineer profile. Proceedings of the 2005 American Society for Engineering Education Annual Conference \& Exposition.

Erdogan, I., \& Campbell, T. (2008). Teacher questioning and interaction patterns in classrooms facilitated with differing levels of constructivist teaching practices. International J ournal of Science Education, 30(14), 1891-1914. 
Eraut, M. (1994). Developing professional knowledge and competence. London: Falmer Press.

Fulford, C.P., \& Sakaguchi, G. (2002). Validating a taxonomy of interaction strategies for two-way interactive distance education television. International J ournal of Instructional Media, 29(1), 79-92.

Gilbert, L., \& Moore, D. R. (1998). Building interactivity into web courses: Tools for social and instructional interaction. Educational Technology, 38(3), 29-35.

Gordon, S. G., Sorensen, C., Gump, A., Heindel, A., Caris, M., \& Martinez, C. (2011). Overcoming student resistance to group work: Online versus face-to-face. The Internet and Higher Education, 14(2), 121-128.

Gorsky, P., Caspi, A., Antonovsky, A., Blau, I., \& Mansur, A. (2010). The relationship between academic discipline and dialogic behavior in open university course forums. International Review of Research in Open and Distance Learning, 11(2), 49-72.

Guan, J ., Tregonning, S., \& Keenan, L. (2008). Social interaction and participation: Formative evaluation of online CME modules. J ournal of Continuing Education in the Health Professions, 28(3), 172-179.

Hong, S., \&J ung, I. (2012). The distance learner competencies: A three-phased empirical approach. Educational Technology Research and Development, 59(1), 21-42.

Hunter, J . (2008). Applying constructivism to nursing education in cultural competence. J ournal of Transcultural Nursing, 19(4), 354-362.

Hurumi, A. (2006). Analyzing and designing e-learning interaction. In C. J uwah (Ed.), Interactions in online education. Implications for theory \& practice (pp.46-72). New York: Routledge.

J anesick, V.J . (2003). The choreography of qualitative research design? Minuets, improvisations, and crystallization. In N. K. Denzin \&Y. S. Lincoln (Eds.), Strategies of qualitative inquiry (2nd ed., pp. 46-79). Thousand Oaks, CA: Sage.

J eris, L., \&J ohnson, K. (2004). Speaking of competence: Toward a cross-translation for human resource development (HRD) and continuing professional education (CPE). In T. Egan, M. Morris \& V. Inbakumar (Eds.), Proceedings of Academy of Human Resource Development, 2 (pp. 1103-1110). Austin, TX.

J uwah, C. (2006). Interactions in online education. Implications for theory \& practice. New York: Routledge.

Kale, U. (2008). Levels of interaction and proximity: Content analysis of video-based classroom cases. Internet and Higher Education, 11(2), 119-128. 
Ke, F. (2013). Online interaction arrangements on quality of online interactions performed by diverse learners across disciplines. Internet and Higher Education, 16, 14-22.

Keengwe, J ., \& Schnellert, G. (2012). Fostering interaction to enhance learning in online learning environments. International J ournal of Information and Communication Technology Education, 8(3), 28-35.

Kelly, G. J ., Luke, A., \& Green, J . (2008). Introduction. In G. J . Kelly, A. Luke \&J . Green (Eds.), Review of research in education Volume 32: What counts as knowledge in educational settings: Disciplinary knowledge, assessment, and curriculum (pp. vii-x). Thousand Oaks, CA: SAGE.

Loewen, S., \& Reissner, S. (2009). A comparison of incidental focus on form in the second language classroom and chatroom. Computer Assisted Language Learning, 22(2), 101-114.

Manca, S., Delfino, M., \& Mazzoni, E. (2009). Coding procedures to analyse interaction patterns in educational Web forums. J ournal of Computer Assisted Learning, 25(2), 189-200.

Masoumi, D., \&Lindström, B. (2012). Quality in e-learning: A framework for promoting and assuring quality in virtual institutions. J ournal of Computer Assisted Learning, 28(1), 27-41.

Monaghan, L., Goodman, J .E., \& Meta R. J . (Eds.). (2012). A cultural approach to interpersonal communication. Oxford: Wiley-Blackwell

Moore, M. G. (1989). Editorial: three types of interaction. The American J ournal of Distance Education, 3(2), 1-7.

Nandi, D., Hamilton, M., \& Harland, J . (2012). Evaluating the quality of interaction in asynchronous discussion forums in fully online courses. Distance education, 33(1), 5-30.

Nesi, H., \& Gardner, S. (2006). Variation in disciplinary culture: University tutors views on assessed writing tasks. In G. Clibbon, T. Kiely, P. Rea-Dickins, H. Woodfield (Eds.), British studies in applied linguistics, Volume 21: Language, culture and identity in applied linguistics (pp. 97-117). U.K.: Equinox Publishing.

Pfeffer, T. (2012). Competences for the effective use of educational technologies at universities. In T. Pfeffer (Ed.). Virtualization of universities. Innovation technology and knowledge management (pp.141-163). New York: Springer.

PISA Report. (n.d.). Retrieved from http:// www.oecd.org/pisa/35070367.pdf.

Quality Matters. (2011). Quality Matters rubric standards 2011 - 2013 edition with assigned point values. Retrieved from https:// www.qualitymatters.org/ rubric 
Roblyer, M. D., \&Wiencke, W. R. (2004). Exploring the interaction equation: Validating a rubric to assess and encourage interaction in distance courses. J ALN, 8(4), 25-37.

Rychen, D.S., \& Salganik, L.H., (Eds). (2001). The definition and selection of key competencies. DeSeCo Publications.

Silius, K., Tervakari, A.M., Kailanto, M., Huhtamäki, J ., Marttila, J ., Tebest, T., \& Miilumäki, T. (2012). Developing an online publication collaborating among students in different disciplines. Proceedings of the 20112 nd international congress on computer applications and computational science: Advances in Intelligent and Soft Computing, Volume 144.

Snášel, V., Abraham, A., Martinovič, J., Dráždilová, P., Slaninová, K., Daradoumis, T., Xhafa, F., \& Martínez-Monés, A. (2012). E-assessment of individual and group learning processes. J ournal of Computational and Theoretical Nanoscience, 9(2), 286-303.

Squires, G. (2005) Art, science and the professions. Studies in Higher Education, 30, 127- 36.

Stark, J . S. (2000). Planning introductory college courses: Content, context and form. Instructional Science, 28, 413-438.

Stark, J . S., Lowther, M. A., Bentley, R. J ., \& Martens, G. G. (1990). Disciplinary differences in course planning. Review of Higher Education, 13(2), 141-165.

Tsai, C., \& Lee, T. (2012). Developing an appropriate design for E-learning with Webmediated teaching methods to enhance low-achieving students' computing skills: Five studies in E-learning implementation. International J ournal of Distance Education Technologies, 10(1), 1-30.

Tseng, H. W., \&Yeh, H. T. (2013). Team members' perceptions of online teamwork learning experiences and building teamwork trust: A qualitative study. Computers and Education, 63, 1-9.

\section{Athabasca University $\mathbf{a}$}

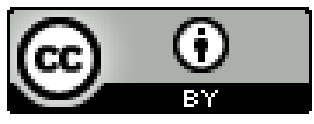

